\title{
RADIOCARBON EVIDENCE FOR THE EARLY BRONZE AGE LEVANT: THE SITE OF TELL FADOUS-KFARABIDA (LEBANON) AND THE END OF THE EARLY BRONZE III PERIOD
}

\author{
Felix Höflmayer ${ }^{1} \cdot$ Michael W Dee $^{2} \cdot$ Hermann Genz $^{3} \cdot$ Simone Riehl $^{4}$
}

ABSTRACT. Absolute dates for the end of the Early Bronze Age ancient Near East are of crucial importance for assessing the nature and extent of mid- to late 3rd millennium BC transitions in the Near East and their alleged link to the 4.2ka BP climatic event. This article presents a radiocarbon sequence for the Early Bronze Age site of Tell Fadous-Kfarabida (Lebanon) and argues that the end of the Early Bronze III period has to be dated considerably higher than previously estimated. There is no reason to assume that the $4.2 \mathrm{ka} \mathrm{BP}$ event might have contributed to or even triggered the collapse of the first urban cities in the southern and central Levant.

\section{INTRODUCTION}

Until recently, absolute dates for chronological phases of the Early Bronze Age central and southern Levant were mainly based on archaeological synchronization with Old Kingdom Egypt and, therefore, ultimately, on calendar dates for the Egyptian historical chronology. Egyptian objects in the Levant and Levantine pottery found in Egyptian tombs provided a general scheme for correlation and also written and pictorial sources like the autobiography of Weni the Elder or the depictions of walled towns in a 5th Dynasty tomb in Deshasheh were used for establishing a chronological framework for the period (Petrie 1898; de Miroschedji and Sadek 2001; Richards 2002; Sowada 2009; Knoblauch 2010; de Miroschedji 2012).

Based on this scheme, Early Bronze I was dated from $~ 3700$ to $3100 / 3000$ BC and correlated with the Egyptian Predynastic period whereas the Early Bronze II-III was dated from $\sim 3100$ to 2300 BC and correlated with the Egyptian Protodynastic period and the Old Kingdom down to the late 6th Dynasty. Early Bronze IV (also called the Intermediate Bronze Age) was dated from 2300 to $2000 \mathrm{BC}$, to the onset of the Middle Bronze Age, and roughly correlated with the First Intermediate period in Egypt (de Miroschedji 2009; Sowada 2009; Harrison 2012).

While the Early Bronze II-III period saw the rise of strong fortified urban centers throughout the southern and central Levant, almost all of these "first cities" collapsed at the end of the Early Bronze III period and the subsequent Early Bronze IV was characterized by small rural villages and a presumed return to pastoralism. For parts of the northern Levant, a different scenario can be suggested, as sites in western Syria and along the northern coast of Lebanon demonstrate a continuation of urban structures into the Early Bronze Age IV (de Miroschedji 2009; Parr 2009; Genz 2010b, 2012; Harrison 2012). Based on the abandonment of a number of sites, especially in the southern Levant, widespread collapse has been assumed, and was explained with different scenarios. For a long time, it was thought the Amorites played a crucial role in the destruction of the fortified centers and were instigators of the pastoralist Intermediate Bronze Age (Wright 1961; Kenyon 1966; Dever 1970). Other scholars correlated the end of the first cities with Egyptian military campaigns of the late 6th Dynasty into the southern Levant (Mazar 1968; Callaway 1978). In recent years, however, it has

1. University of Chicago, The Oriental Institute, 1155 East 58th Street Chicago, Illinois 60637, USA. Corresponding author. Email: fhoeflmayer@uchicago.edu.

2. RLAHA, University of Oxford, Oxford OX1 3QY, United Kingdom.

3. American University of Beirut, Lebanon.

4. Universität Tübingen, Germany.

Proceedings of the Radiocarbon and Archaeology 7th International Symposium

Ghent, Belgium, April 2013 | Edited by Mark Van Strydonck, Philippe Crombé, and Guy De Mulder

(C) 2014 by the Arizona Board of Regents on behalf of the University of Arizona 
been argued that the rapid climate change during the late $3 \mathrm{rd}$ millennium BC (the $4.2 \mathrm{ka} \mathrm{BP}$ event), observable in many different proxies all over the world, might have triggered supraregional decline due to aridification and cooling, resulting in the collapse of the Akkad Empire in Upper Mesopotamia, the fall of the first cities in the southern Levant and, finally, the end of the Old Kingdom in Egypt (Weiss et al. 1993; Weiss 2000a,b; Weiss and Bradley 2001; Staubwasser and Weiss 2006; Miller Rosen 2007; Weiss 2012). However, it has to be stressed that the contemporaneity of these collapses and their extent and nature are highly debated (Moeller 2005; Pfälzner 2012; Ur 2012) and that the general and local outline of climate geography in these areas, as well as the archaeobotanical and stable isotope evidence from cereal grains, support a high interregional variability in climate effects (Riehl and Bryson 2007; Riehl 2012).

Precise absolute dating of the demise of the urbanized Early Bronze Age II-III sites is of crucial importance for assessing the different explanations for this phenomenon that have been put forward. This contribution reports on a new radiocarbon sequence for the site of Tell Fadous-Kfarabida (Lebanon) that has considerable bearing on this question.

\section{THE SITE OF TELL FADOUS-KFARABIDA}

Tell Fadous-Kfarabida is situated on the Mediterranean coast of Lebanon, $\sim 12 \mathrm{~km}$ north of Byblos. The site has been excavated by the American University of Beirut under the direction of Hermann Genz and Hélène Sader from 2007 onwards, after two preliminary campaigns in 2004 and 2005. Six archaeological phases ranging from the Chalcolithic to the Middle Bronze have been attested at this rather small ( $\sim 1.5 \mathrm{ha})$ fortified site. In the following, a short summary is presented of the archaeological dating and synchronisms of the six phases and the ${ }^{14} \mathrm{C}$ evidence for the site is discussed (Badreshany et al. 2005; Genz and Sader 2007, 2008; Badreshany and Genz 2009; Genz 2009, 2010a; Genz et al. 2009, 2010).

Phase I (Chalcolithic/Early Bronze Age I) is comparable with the Énéolithique récent at Byblos and is only attested by two child burials in jars, with no architecture of this period being found. These earliest activities are separated from the Early Bronze Age city of phases II-IV by an unknown length of time (Table 1).

Phases II to IV are attributed to the Early Bronze Age II and III periods and represent the main occupation phase. While Phase II is so far only attested in a small sounding below Building 1, Phase III is represented by buildings, narrow streets, and fortification. In Phase IV, several buildings were abandoned and replaced with a large structure of administrative or representational character. Based on pottery, Phase II can be compared with Niveau 18 at Tell Arqa, Phase III with Tell Arqa early Niveau 17 or Sidon Stratum 5, and Phase IV with Arqa late Niveau 17 and Sidon Stratum 6. Several examples of ram's head applications on pottery are attested in phases III and IV, an example of which is also found on a Lebanese import from 4th Dynasty Giza (Tomb G 7330 A: Sowada 2009; Genz, forthcoming).

Table 1 Synchronization of Tell Fadous-Kfarabida, Tell Arqa, traditional and ARCANE periodization (Mazzoni and Thalmann, forthcoming).

\begin{tabular}{llll}
\hline Tell Fadous-Kfarabida & Tell Arqa & Traditional periodization & ARCANE periodization \\
\hline Phase II & Arqa 18 & Early Bronze II & Early Central Levant 3 \\
Phase III & Arqa 17 early & Early Bronze III & Early Central Levant 4 \\
Phase IV & Arqa 17 late & Early Bronze III & Early Central Levant 4 \\
Hiatus ? & Arqa 16 & Early Bronze IV & Early Central Levant 5 \\
Phase V & Arqa 15 & Early Bronze IV & Early Central Levant 6 \\
\hline
\end{tabular}


Phase $\mathbf{V}$ is dated to the Early Bronze Age IV period and is represented by squatter occupation including stone-lined storage pits. Pottery parallels come from Tell Arqa Niveau 15. Phase VI, finally, is dated to the Middle Bronze Age and is so far only represented by burials and pits.

The hiatus between phases IV and V is not really clear in the stratigraphic record of the site, but is rather postulated due to a comparison of the pottery from Tell Fadous-Kfarabida with the evidence from Tell Arqa, located $40 \mathrm{~km}$ to the north (Thalmann 2006). Throughout the 3rd millennium, the pottery assemblages of the two sites are virtually identical. However, material corresponding to Niveau 16 at Tell Arqa is absent at Tell Fadous-Kfarabida, thus suggesting a (short?) hiatus in the occupation of the site.

\section{RADIOCARBON EVIDENCE}

In recent years, a set of 32 short-lived samples has been collected for ${ }^{14} \mathrm{C}$ dating. Most were found in Phase II-V contexts (Early Bronze Age II-IV), while only one sample came from Phase I (Chalcolithic/Early Bronze I) and three samples from Phase VI (Middle Bronze Age). However, since a considerable hiatus between Phase I and Phase II as well as between Phase V and Phase VI can be assumed, this contribution will focus on phases II-V, including the important transition from Early Bronze III to IV (comprising a total of 28 measurements). All samples consisted of olive pits or charred seeds (Table 2).

${ }^{14} \mathrm{C}$ determinations were made in three different laboratories, the Leibniz-Labor für Altersbestimmung und Isotopenforschung in Kiel (lab code KIA), the Vienna Environmental Research Accelerator (lab code VERA), and the Oxford Radiocarbon Accelerator Unit (lab code OxA). Measurements were obtained within the framework of the excavation of Tell Fadous-Kfarabida, and drew upon financial support from the Faculty of Arts and Sciences of the American University of Beirut and the Gerda Henkel-Foundation (data from Kiel), the SCIEM-2000 project of the Austrian Academy of Sciences funded by the Austrian Research Fund (data from Vienna), and the Bronze Age Radiocarbon Dating project of the German Archaeological Institute and the University of Oxford funded by the Fritz Thyssen-Foundation (data from Oxford). Calibrations were made using the OxCal v 4.2 software (Bronk Ramsey 1995, 2009) against the IntCal09 ${ }^{14} \mathrm{C}$ calibration curve interpolated to yearly intervals (resolution $=1$ ) $($ Reimer et al. 2009).

Figure 1 shows the calibrated results for phases I to VI. Although the data are generally very consistent (especially Phase III), the calibrated age ranges are considerably broad, spanning in some cases more than 200 calendar years, due to the shape of the ${ }^{14} \mathrm{C}$ calibration curve, which is rather flat during the first half of the 3rd millennium BC (see Figure 2). From the calibrated age ranges, a few samples can be detected that obviously are not in agreement with the succeeding stratigraphic phases. These probably represent residual material from earlier phases. This holds true for the two oldest samples from Phase IV (KIA-43196 and KIA-43194) as well as for the two oldest samples from Phase V (OxA-25689 and OxA-25616). Also, two of the three Middle Bronze Age samples turned out to be of Early Bronze Age date, well in accordance with other results from phases IIIV (Early Bronze Age II-III), while the third sample dates to the second half of the 19th or early 18th century BC and seems to be representative for the Middle Bronze Age (Genz et al. 2010).

These six samples produced considerably older dates than the majority of the samples from their respective preceding phases. This can be explained by the long settlement history at the site where occasional residual material can be found in much younger contexts, which usually is also the case with pottery, where Early Bronze Age sherds can turn up in Middle Bronze Age strata. Samples from phases III and IV were taken from floor contexts whenever possible, whereas for phases V and 


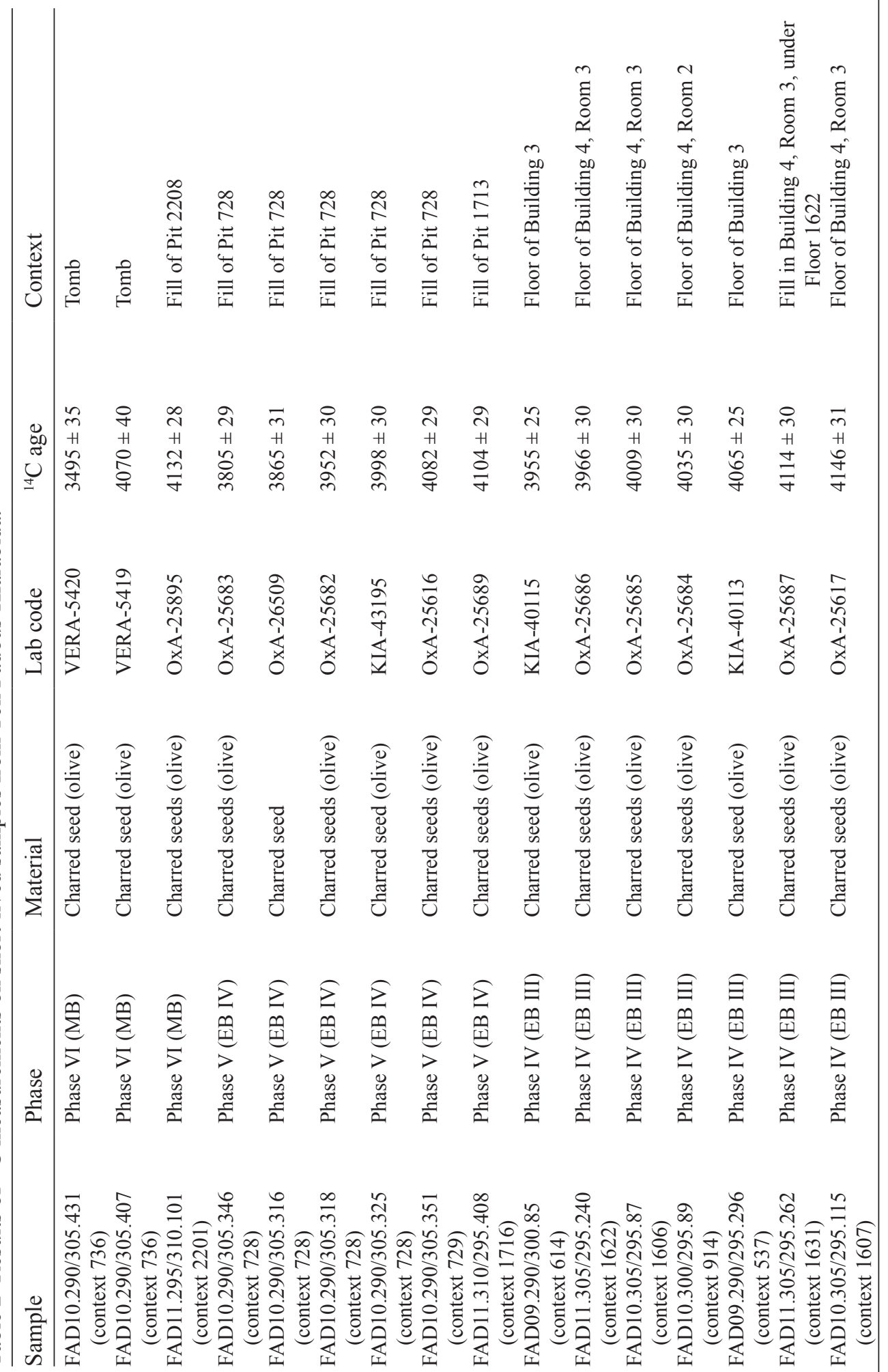




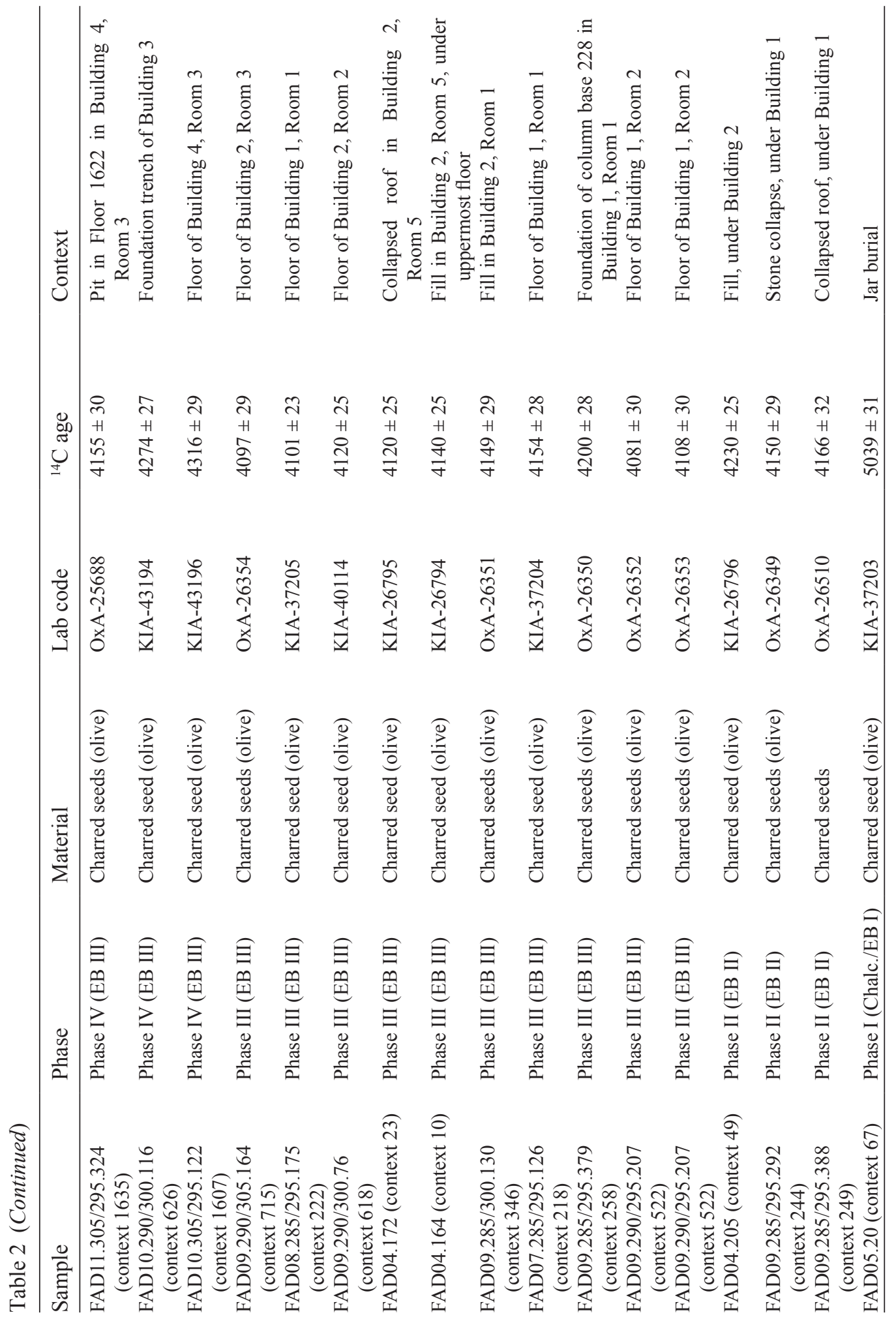




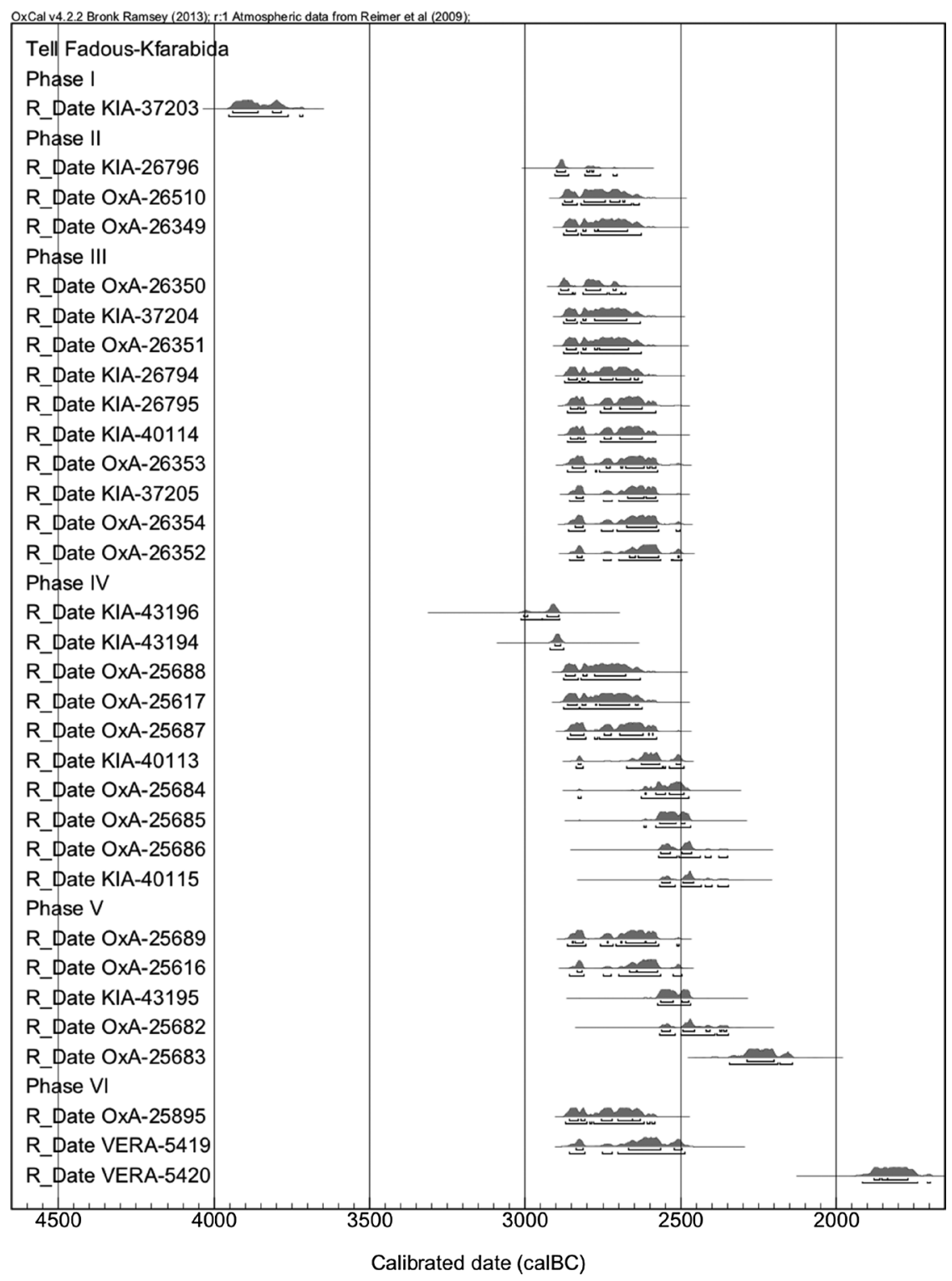

Figure 1 Calibrated ${ }^{14} \mathrm{C}$ determinations for short-lived samples from the Tell Fadous-Kfarabida site (Lebanon)

VI pits and tombs were the only available contexts. During the processing of the pottery from the Phase V and VI pits, it was noticed that they contained a considerable quantity of residual earlier sherd material. Thus, it is quite possible that some of the olive pits selected for analysis originated from earlier contexts as well.

Due to the lack of precision provided by the calibrated results, a Bayesian probability approach was employed to make use of the archaeological stratigraphy of the site. Three different models were calculated (A-C). In order to test, in as objective a manner as possible, which samples were most likely to be outliers, the General Outlier Model analysis (Bronk Ramsey 2009) was employed. 


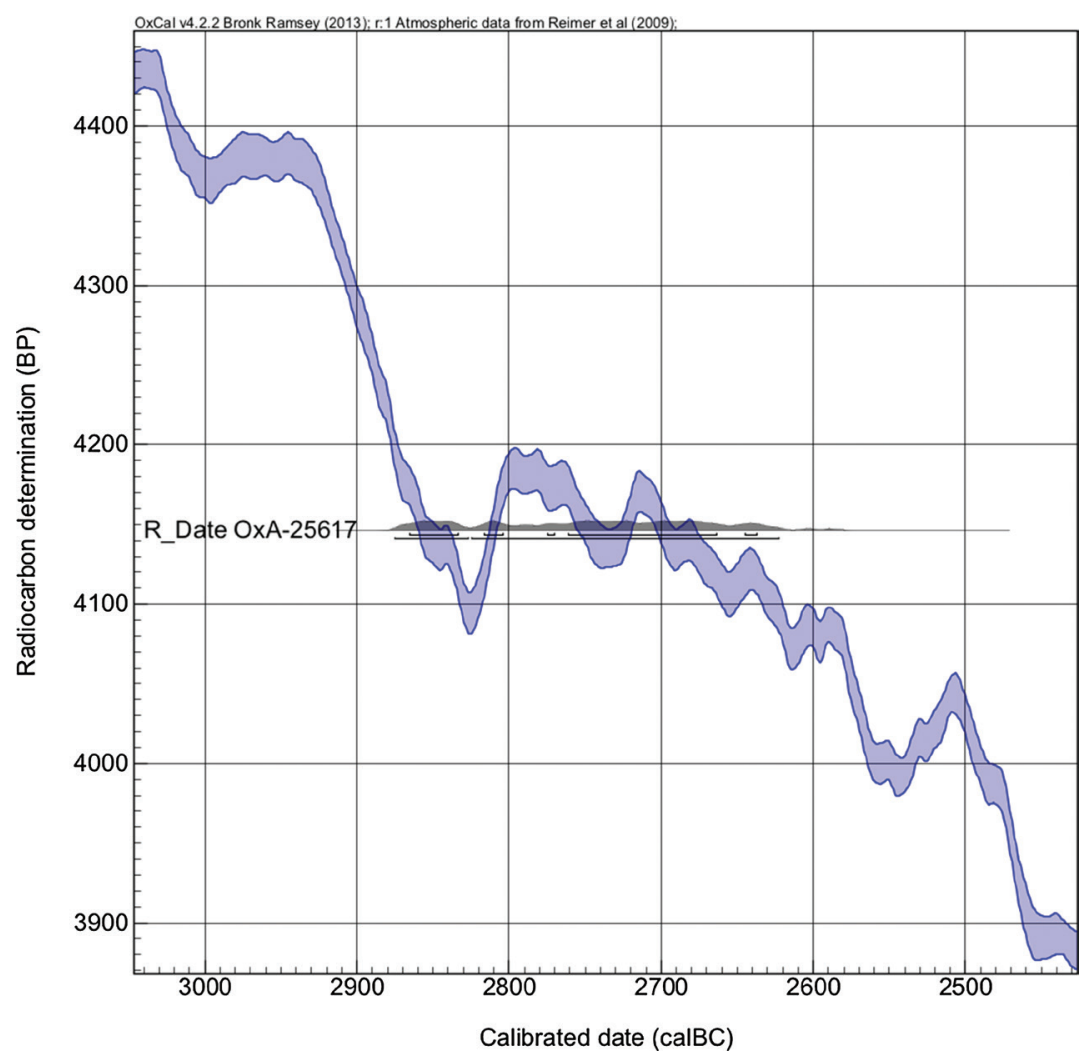

Figure 2 Calibrated ${ }^{14} \mathrm{C}$ determination for typical sample of Phase IV (OxA-25617) against the IntCa109 calibration curve.

For Model A, it was assumed that all samples were representative of the archaeological "phase" in which they were found and that phases II-V were in their correct chronological order (meaning Phase II was older than Phase III and so on). Within each phase, the order of the individual samples was taken to be unknown. Using this assumption, samples originating from a given archaeological phase were grouped together using the Phase function (being an unordered group of events, see Buck et al. 1991; Bronk Ramsey 1995). The "phases" were then placed in chronological order and separated by "boundaries" (reflecting the transition points between them).

For Model B, a hiatus between phases IV (EB III) and V (EB IV) of unknown length was assumed based on the pottery comparison between Tell Fadous-Kfarabida and Tell Arqa outlined above. The hiatus was modeled by placing two "boundaries" between "phases" IV and V.

For Model C, also the hiatus between phases IV and V was again employed, but an additional change was also made purely to examine its effect on the Phase IV/V transition. The four oldest dates for Phase V (OxA-25689, OxA-25616, KIA-43195, and OxA-25682) were excluded because they appeared to be similar in age to samples from Phase IV. Hence, in Model C only sample OxA25683 was treated as being representative of Phase V. It is explicitly stated, though, that this "handpicked" model should be treated with caution. It is included in this publication to show that even if only the youngest date for archaeological Phase V was correct, the end date for archaeological Phase IV still does not shift considerably. 


\section{DISCUSSION}

\section{Model A}

Figure 3 shows the modeled probability ranges of each sample and the transitions (boundaries) between respective archaeological phases. Figure 4 shows the calculated result for the transition from archaeological Phase II (Early Bronze II) to archaeological Phase III (Early Bronze III), and Figure 5, the transition from archaeological Phase IV (Early Bronze III) to archaeological Phase V (Early Bronze IV).

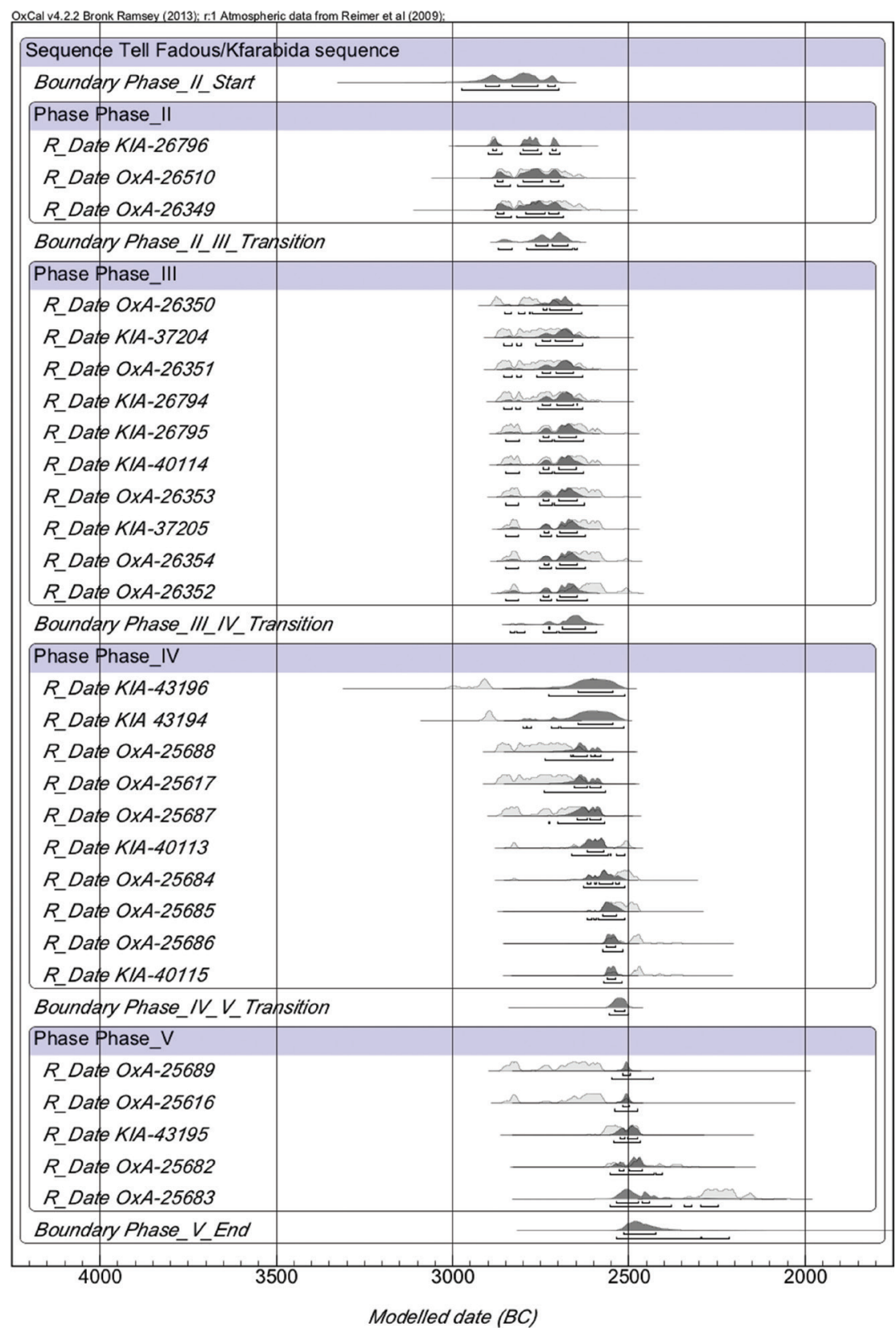

Figure 3 Modeled age ranges for samples of archaeological phases II to V based on Model A 


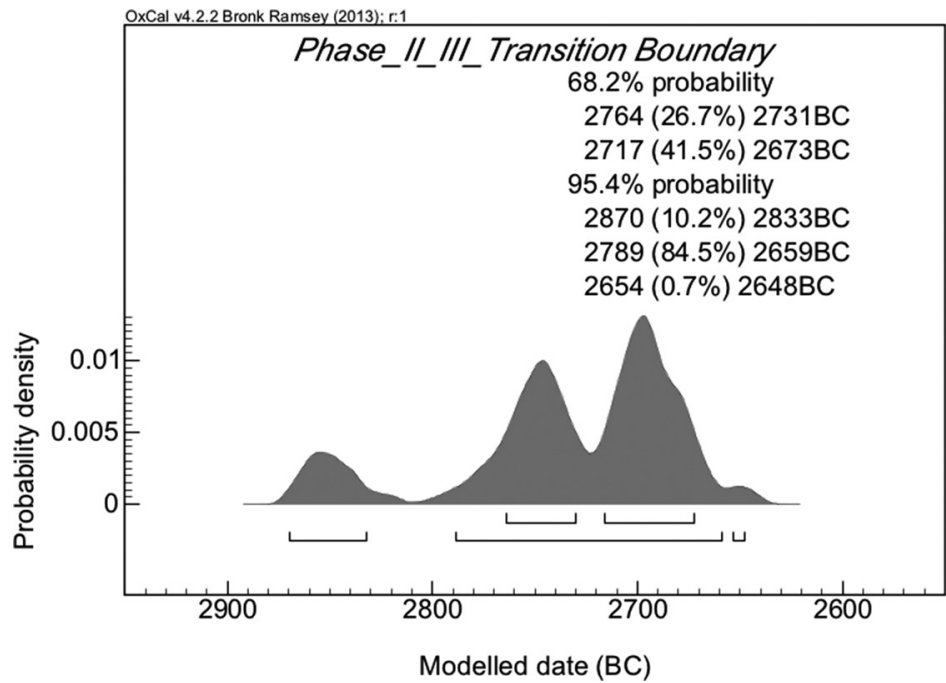

Figure 4 Calculated date for transition from Phase II (Early Bronze Age II) to Phase III (Early Bronze

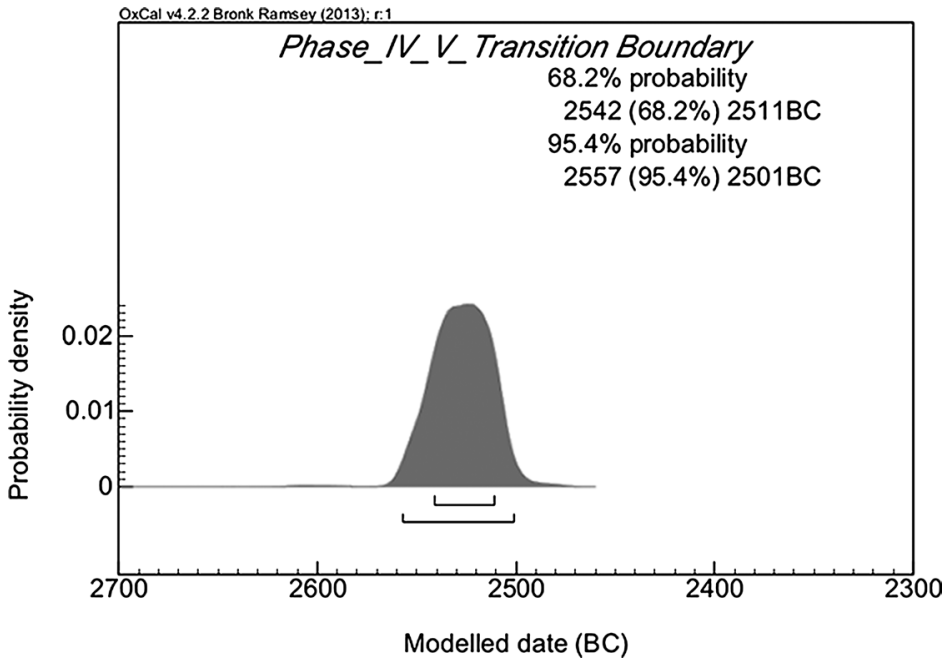

Age III) based on Model A.

Figure 5 Calculated date for transition from Phase IV (Early Bronze Age III) to Phase V (Early Bronze Age IV) based on Model A.

Based on this model, the transition from Phase II (Early Bronze II) to Phase III (Early Bronze III) is still ill defined and seems to have taken place somewhere between 2850 and 2650 BC (Figure 4). This long timespan is due to the rather flat shape of the ${ }^{14} \mathrm{C}$ calibration curve between $\sim 2900$ and 2600 BC (compare also Figure 2). However, further dates from Phase II, which is at the moment only represented by three samples, might increase the precision. While Phase II is correlated with Niveau 18 at Tell Arqa, Phase III can be synchronized with early Niveau 17. Based on ${ }^{14} \mathrm{C}$ evidence from Tell Arqa, Niveau 17 started about 2700/2650 BC (Köhler and Thalmann 2014), and therefore is probably slightly younger than the Phase II/III transition at Tell Fadous-Kfarabida but still in general agreement with it.

The date for the transition from Early Bronze III to Early Bronze IV (shift from Phase IV to V), however, is considerably higher than usually suggested. Based on Model A, the transition took place between $\sim 2550$ and $2500 \mathrm{BC}$ (Figure 5), while usually the Early Bronze III period is synchronized with the Egyptian Old Kingdom (3rd-6th dynasties), ending at about 2300 BC. Phase IV can be correlated with Tell Arqa Niveau 17 late and Phase V is correlated with Tell Arqa 15, while pottery 
typical of Tell Arqa 16 does not show up in Tell Fadous-Kfarabida (a hiatus between Phase IV and $\mathrm{V}$ is assumed in models $\mathrm{B}$ and $\mathrm{C}) .{ }^{14} \mathrm{C}$ evidence for the transition from Tell Arqa Niveau 17 to Niveau 16 dates to $\sim 2500 / 2450$ BCE (Köhler and Thalmann 2014). Again, Tell Arqa seems to be slightly younger but is in general agreement with the results from Tell Fadous-Kfarabida.

\section{Model B}

For Model B, a hiatus of unknown length has been assumed between Phase IV and Phase V, represented in the model by two boundaries. Figure 6 shows the end date of Phase IV and Figure 7 the start for Phase V. Both dates fall between $\sim 2550$ and $2500 \mathrm{BC}$, and there is virtually no difference between Model A and Model B.

Figure 6 Calculated date for end of Phase IV (Early Bronze Age III) based on Model B.

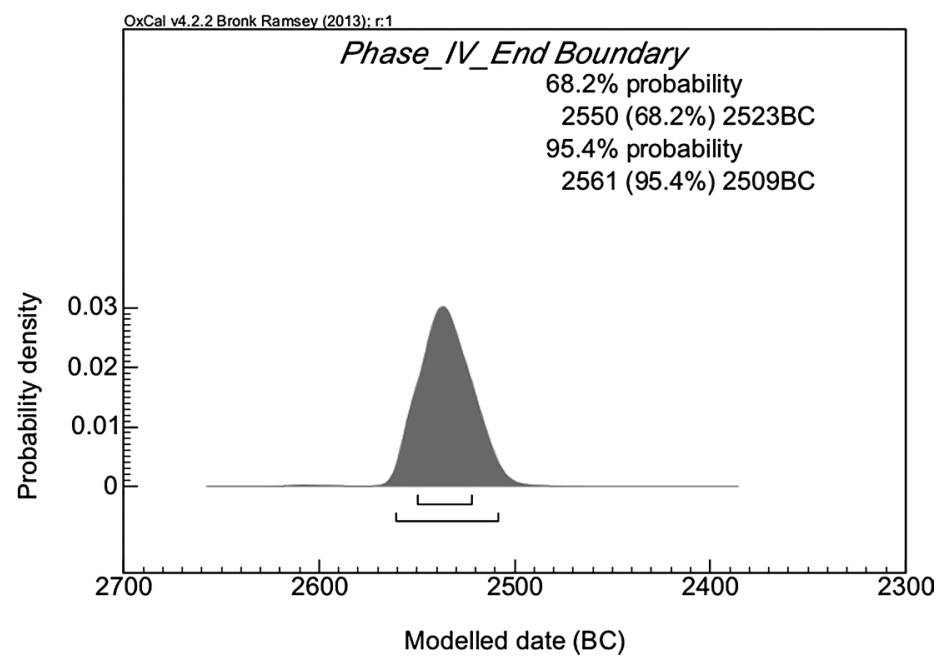

Figure 7 Calculated date for start of Phase V (Early Bronze Age IV) based on Model B.

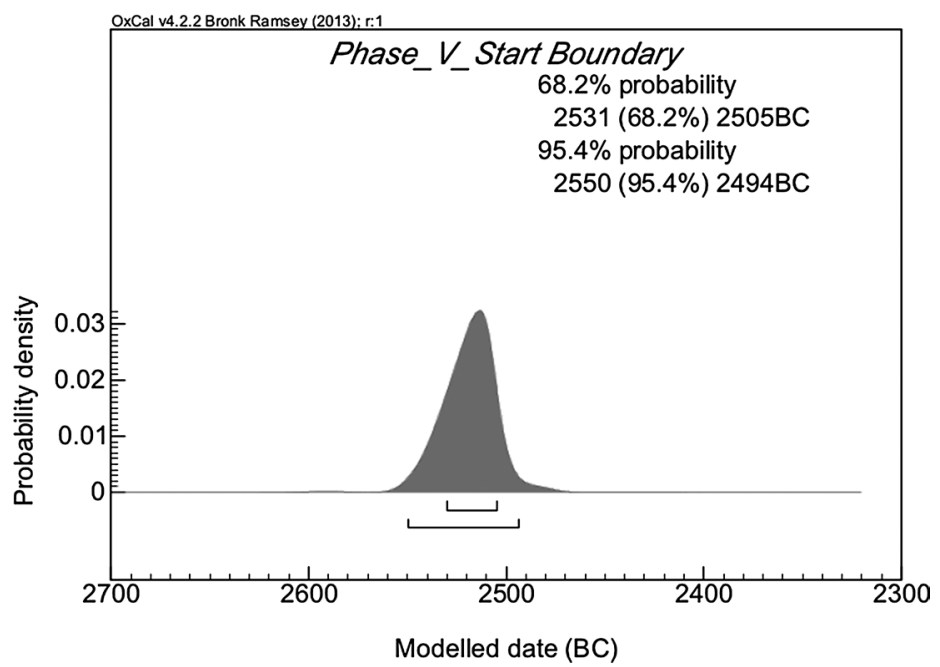

\section{Model C}

For Model C, also a hiatus of unknown length has been assumed, but in addition four samples from Phase V that yielded ages similar to samples from Phase IV (OxA-25689, OxA-25616, KIA-43195, and OxA-25682) have been excluded and only the youngest sample (OxA-25683) is being used for Phase V. This should allow for more flexibility for the end of Phase IV. It has to be stated though 
that removing dates in this way is inadvisable and it was done in this case only to check how low the end date for Phase IV could be if all four dates were errant (Figure 8). As can be seen in the figure, the calculated age range for the end of Phase IV becomes elongated, but still falls around $2500 \mathrm{BC}$, although it now includes the first half of the 25 th century $\mathrm{BC}$ in its $1 \sigma$ range.

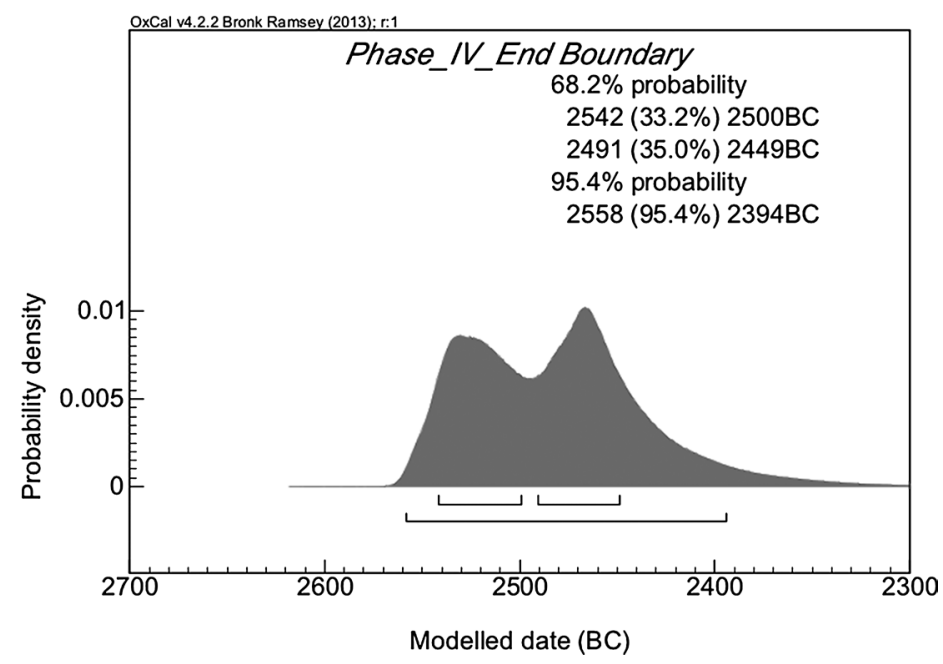

Figure 8 Calculated date for end of Phase IV (Early Bronze Age III) based on Model C.

\section{CONCLUSIONS}

Based on the presented evidence, the transition from Early Bronze III to Early Bronze IV falls in the mid-3rd millennium ( $\sim 2500 \mathrm{BC}$, or slightly before) and not at $\sim 2300 \mathrm{BC}$ as conventionally suggested. This evidence is based on a Bayesian model with $28{ }^{14} \mathrm{C}$ determinations from short-lived samples and stratigraphic evidence and is in agreement with ${ }^{14} \mathrm{C}$ dates from the nearby site of Tell Arqa.

Further evidence for an early date comes from the southern Levant. Within the framework of the ARCANE (Associated Regional Chronologies of the Ancient Near East) project, a comprehensive sequence of ${ }^{14} \mathrm{C}$ dates was published for the Early Bronze Age site of Tel Yarmuth (Regev et al. 2012a). This sequence, starting within the Early Bronze Age I period and ending with the end of the Early Bronze Age III, sometimes produced dates that were considerably higher than previously expected. This is especially true for the end for the Early Bronze Age III, which produced results that were up to $200 \mathrm{yr}$ older than dates based on current archaeological and historical understanding. According to the recent study of Regev et al. (2012a), the end of the Early Bronze Age III period at Tel Yarmuth should be $\sim 2500 \mathrm{BC}$ ( $\sim 2450 \mathrm{BC}$ at the latest).

Another study by Regev et al. (2012b) for other sites in the southern Levant came to similar conclusions. Based on a set of over 100 dates for the Early Bronze Age from several sites, the authors argued for a transition from Early Bronze I to II between 3200 and 2900 BC, well in agreement with archaeological estimates and a transition from Early Bronze III to IV around 2500 BC, and in perfect agreement with the results reported here from Tell Fadous-Kfarabida.

Also, ${ }^{14} \mathrm{C}$ measurements on short-lived samples from the Early Bronze IV site of Tell Abu en-Nicaj in the northern Jordan Valley provided dates roughly between 2500 and 2300 BC, also implying an EB III/IV transition well before 2300 BC (Bronk Ramsey et al. 2002:82). 
The end of the Early Bronze III period was usually dated to $2300 \mathrm{BC}$ and synchronized with the late Old Kingdom (6th Dynasty). Although one could argue that the Egyptian historical chronology should be raised accordingly in order to maintain the synchronism between the end of Early Bronze III and the late Old Kingdom, at the moment there is no indication that a rise in Old Kingdom Egyptian chronology might be in order. The Oxford project on Radiocarbon Dating and the Egyptian Chronology showed conclusively that ${ }^{14} \mathrm{C}$ dating is in general agreement with the historical chronology of Egypt. Although slightly higher dates for the 5th and 6th Dynasty of the order of 50 to $70 \mathrm{yr}$ could be possible, at the moment there is no reason to shift the Egyptian Old Kingdom back in time by $\sim 200$ yr (Bronk Ramsey et al. 2010).

Therefore, such an early date for the end of the first urbanization in the southern Levant — if it could be substantiated at other sites as well-would disconnect the end of the Early Bronze III period from the end of the Egyptian Old Kingdom and instead move it back somewhere within the late 4th or early 5th Dynasty. This would also fit the Lebanese pottery vessel with a ram's head application from the 4th Dynasty tomb at Giza with parallels from phases III and IV (Early Bronze III) of Tell Fadous-Kfarabida (see above; Tomb G 7330 A; Sowada 2009; Genz, forthcoming).

Such an early date corroborates critical notions on the possibility of an exact dating of the $4.2 \mathrm{ka}$ BP climatic event and its categorical application on cultural change in general, and as a possible trigger for the collapse of the urban centers of the Early Bronze II-III period in particular. Taking the local $\delta^{18} \mathrm{O}$ and $\delta^{13} \mathrm{C}$ ratios from Soreq Cave into account, it becomes clear that a continuous decrease in precipitation took place throughout the 3rd millennium $\mathrm{BC}$, roughly starting around 4.7 ka BP (Bar-Matthews and Ayalon 2011). Taking human endurability and the potential to act on environmental change into account, our results suggest long-term environmental change in the 3rd millennium BC was accompanied by locally very diverse developments in human societies and economies. Any alleged Egyptian military campaigns to the southern Levant during the 6th Dynasty can also be excluded on the basis of our results. From the ${ }^{14} \mathrm{C}$ evidence, it is clear that the collapse of the first cities at the end of Early Bronze III around $2500 \mathrm{BC}$ is considerably earlier than the end of the Akkad Empire and the end of the Egyptian Old Kingdom.

\section{REFERENCES}

Badreshany K, Genz H. 2009. Pottery production on the northern Lebanese coast during the Early Bronze Age II-III: the petrographic analysis of the ceramics from Tell Fadous-Kfarabida. Bulletin of the American Schools of Oriental Research 355:51-83.

Badreshany K, Genz H, Sader H. 2005. An Early Bronze Age site on the Lebanese coast: Tell Fadous-Kfarabida 2004 and 2005: final report. Bulletin d'archéologie et d'architecture libanaises 9:5-115.

Bar-Matthews M, Ayalon A. 2011. Mid-Holocene climate variations revealed by high-resolution speleothem records from Soreq Cave, Israel and their correlation with cultural changes. The Holocene 21(1):163-71.

Bronk Ramsey C. 1995. Radiocarbon calibration and analysis of stratigraphy: the OxCal program. Radiocarbon 37(2):425-30.

Bronk Ramsey C. 2009. Dealing with outliers and offsets in radiocarbon dating. Radiocarbon 51(3):1023-45.

Bronk Ramsey C, Higham TFG, Owen DC, Pike AWG, Hedges REM. 2002. Radiocarbon dates from the
Oxford AMS System: Archaeometry Datelist 31. Archaeometry 44(3):1-149.

Bronk Ramsey C, Dee MW, Rowland JM, Higham TFG, Harris SA, Brock F, Quiles A, Wild EM, Marcus ES, Shortland AJ. 2010. Radiocarbon-based chronology for dynastic Egypt. Science 328(5985):1554-7.

Buck CE, Litton CD, Smith AFM. 1991. Calibration of radiocarbon results pertaining to related archaeological events. Journal of Archaeological Science 19(5):497-512.

Callaway JA. 1978. New perspectives on Early Bronze III in Canaan. In: Moorey R, Parr P, editors. Archaeology in the Levant. Essays for Kathleen Kenyon. Warminster: Aris \& Phillips. p 46-58.

de Miroschedji P. 2009. Rise and collapse in the Southern Levant in the Early Bronze Age. Scienze dell'Antichità. Storia Archeologia Antropologia 15:101-29.

de Miroschedji P. 2012. Egypt and Southern Canaan in the Third Millennium BCE: Uni's Asiatic campaigns revisited. In: Gruber M, Ahituv S, Lehmann G, Talshir Z, editors. All the Wisdom of the East. 
${ }^{14} \mathrm{C}$ Evidence for the Early Bronze Age Levant

Studies in Near Eastern Archaeology and History in Honor of Eliezer D. Oren. Fribourg: Academic Press. p 265-92.

de Miroschedji P, Sadek M. 2001. Gaza et l'Égypte de l'époque prédynastique à l'Ancien Empire. Premiers résultats des fouilles de Tell es-Sakan. Bulletin de la société française d'égyptologie 152:28-52.

Dever WG. 1970. The "Middle Bronze I" period in Syria and Palestine. In: Sanders JA, editor. Near Eastern Archaeology in the Twentieth Century. Essays in Honor of Nelson Glueck. New York: Doubleday \& Company. p 132-63.

Genz H. 2009. Tell Fadous-Kfarabida: regional connections in the Early Bronze Age. Bulletin d'archéologie et d'architecture libanaises Hors-Série VI:10716.

Genz H. 2010a. Recent excavations at Tell Fadous-Kfarabida. Near Eastern Archaeology 73(2-3):102-13.

Genz H. 2010b. Reflections on the Early Bronze Age IV in Lebanon. In: Matthiae P, Pinnock F, Nigro L, Marchetti N, editors. Proceedings of the 6th International Congress of the Archaeology of the Ancient Near East. 5-10 May 2009, "Sapienza," Università di Roma. Volume 2: Excavations, Surveys and Restorations: Reports on Recent Field Archaeology in the Near East. Wiesbaden: Harrassowitz Verlag. p 205-17.

Genz H. 2012. Bronze Age cities of the northern Levant. In: Potts DT, editor. A Companion to the Archaeology of the Ancient Near East. Malden: Wiley-Blackwell. p 607-28.

Genz H. Forthcoming. Recent developments in Early Bronze Age pottery studies in Lebanon and the question of ceramic exports to Old Kingdom Egypt. In: Rzeuska TI, Wodzińska A. Old Kingdom Pottery Workshop 2

Genz H, Sader H. 2007. Excavations at the Early Bronze Age site of Tell Fadous-Kfarabida: preliminary report on the 2007 season of excavations. Bulletin d'archéologie et d'architecture libanaises 11:7-16.

Genz H, Sader H. 2008. Excavations at Tell Fadous-Kfarabida: preliminary report on the 2008 season of excavations. Bulletin d'archéologie et d'architecture libanaises 12:149-59.

Genz H, Çakırlar C, Damick A, Jastrzębska E, Riehl S, Deckers K, Donkin A. 2009. Excavations at Tell Fadous-Kfarabida: preliminary report on the 2009 season of excavations. Bulletin d'archéologie et d'architecture libanaises 13:71-123.

Genz H, Daniel R, Damick A, Ahrens A, el-Zaatari S, Höflmayer F, Kutschera W, Wild EM. 2010. Excavations at Tell Fadous-Kfarabida. Preliminary report on the 2010 season of excavations. Bulletin d'archéologie et d'architecture libanaises 14:24174.

Harrison TP. 2012. The Southern Levant. In: Potts DT, editor. A Companion to the Archaeology of the Ancient Near East. Malden: Wiley-Blackwell. p 62946.

Kenyon KM. 1966. Amorites and Canaanites: The
Schweich Lectures of the British Academy 1963. London: Oxford University Press.

Knoblauch C. 2010. Preliminary report on the Early Bronze Age III pottery from contexts of the 6th Dynasty in the Abydos Middle Cemetery. Ägypten \& Levante 20:243-61.

Köhler EC, Thalmann J. 2014. Synchronising Early Egyptian chronologies and the Northern Levant. In: Höflmayer F, Eichmann R, editors. Egypt and the Southern Levant during the Early Bronze Age: C14, Chronology, Connections. Proceedings of a Workshop Held in Berlin, 14-16 September 2011. Orient Archäologie 32. Rahden: Marie Leidorf

Mazar B. 1968. The Middle Bronze Age in Palestine. Israel Exploration Journal 18:65-97.

Mazzoni S, Thalmann J-P, editors. Forthcoming. Associated Regional Chronologies for the Ancient Near East and the Eastern Mediterranean: The Central and Northern Levant. Turnhout: Brepols.

Miller Rosen A. 2007. Civilizing Climate. Social Responses to Climate Change in the Ancient Near East. Plymouth: Altamira Press.

Moeller N. 2005. The First Intermediate Period: a time of famine and climate change? Ägypten \& Levante 15:153-67.

Parr P, editor. 2009. The Levant in Transition (The Palestine Exploration Fund Annual 9). Leeds: Maney Publishing.

Petrie WMF. 1898. Deshasheh 1897. Memoir of the Egypt Exploration Fund 15. London: Egypt Exploration Fund

Pfälzner P. 2012. Household dynamics in late Third Millennium northern Mesopotamia. In: Weiss H, editor. Seven Generations since the Fall of Akkad. Wiesbaden: Harrassowitz Verlag. p 145-62.

Regev J, de Miroschedji P, Boaretto E. 2012a. Early Bronze Age chronology: radiocarbon dates and chronological models from Tel Yarmuth (Israel). Radiocarbon 54(3-4):505-24.

Regev J, de Miroschedji P, Greenberg R, Braun E, Greenhut Z, Boaretto E. 2012b. Chronology of the Early Bronze Age in the southern Levant: new analysis for a High Chronology. Radiocarbon 54(3-4):525-66.

Reimer PJ, Baillie MGL, Bard E, Bayliss A, Beck JW, Blackwell PG, Bronk Ramsey C, Buck CE, Burr GS, Edwards RL, Friedrich M, Grootes PM, Guilderson TP, Hajdas I, Heaton TJ, Hogg AG, Hughen KA, Kaiser KF, Kromer B, McCormac G, Manning SW, Reimer RW, Richards DA, Southon JR, Talamo S, Turney CSM, van der Plicht J, Weyhenmeyer CE. 2009. IntCal09 and Marine09 radiocarbon age calibration curves, $0-50,000$ years cal BP. Radiocarbon 51(4):1111-50.

Richards J. 2002. Text and context in late Old Kingdom Egypt: the archaeology and historiography of Weni the Elder. Journal of the American Research Center in Egypt 39:75-102.

Riehl S. 2012. Variability in ancient Near Eastern environmental and agricultural development. Journal of Arid Environments 86:113-21. 
Riehl S, Bryson RA. 2007. Variability in human adaptation to changing environmental conditions in Upper Mesopotamia during the Early to Middle Bronze Age transition. In: Marro C, Kuzucuoglu C, editors. Sociétés humaines et changement climatique à la fin $d u$ troisième millénaire: une crise a-t-elle eu lieu en Haute-Mésopotamie? Varia Anatolica 19. Paris: de Boccard. p 523-48.

Sowada KN. 2009. Egypt in the Eastern Mediterranean during the Old Kingdom: An Archaeological Perspective. Orbis Biblicus et Orientalis 237. Fribourg: Academic Press.

Staubwasser M, Weiss H. 2006. Holocene climate and cultural evolution in Late Prehistoric-Early Historic West Asia. Quaternary Research 66(3):372-87.

Thalmann J. 2006. Tell Arqa I: Les niveaux de l'âge du Bronze. Bibliothèque archéologique et historique 177. Beirut: Institut Français du Proche-Orient.

Ur J. 2012. Spatial scale and urban collapse at Tell Brak and Hamoukar at the end of the Third Millennium BC. In: Laneri N, Pfälzner P, Valentini S, editors. Looking North. The Socioeconomic Dynamics of Northern Mesopotamian and Anatolian Regions during the Late Third and Early Second Millennium $B C$. Wiesbaden: Harrassowitz Verlag.

Weiss H. 2000a. Beyond the Younger Dryas. Collapse as adaptation to abrupt climate change in ancient West Asia and the Eastern Mediterranean. In: Bawden G, Reycraft RM, editors. Environmental Disaster and the Archaeology of Human Response. Albuquerque: Maxwell Museum of Anthropology. p 75-98.

Weiss H. 2000b. Causality and chance. Late Third Millennium collapse in Southwest Asia. In: Rouault $\mathrm{O}$, Wäfler M, editors. La Djéziré et l'Euphrate syriens de la protohistoire à la fin du IIe millénaire av. J.-C. Tendances dans l'interprétation historique des données nouvelles. Turnhout: Brepols. p 207-17.

Weiss H. 2012. Quantifying collapse: the late Third Millennium Khabur Plains. In: Weiss H, editor. Seven Generations since the Fall of Akkad. Wiesbaden: Harrassowitz Verlag. p 1-24.

Weiss H, Bradley RS. 2001. What drives societal collapse? Science 291(5504):609-10.

Weiss H, Courty MA, Wetterstrom W, Guichard F, Senior L, Meadow R, Curnow A. 1993. The genesis and collapse of 3rd Millennium north Mesopotamian civilization. Science 261(5124):995-1004.

Wright GE. 1961. The archaeology of Palestine. In: Wright GE. The Bible and the Ancient Near East. Essays in Honor of William Foxwell Albright. Garden City: Doubleday \& Company. p 73-112. 